UDK 323.284-053.6

https://doi.org/10.18485/fb_ic4hs.2018.11

\title{
JUVENILES INSIDE THE TERRORIST GROUPS
}

\author{
Božidar BANOVIĆ*, Višnja RANĐELOVIĆ ${ }^{* *}$
}

\begin{abstract}
One of the main features of contemporary terrorist groups is an increasing number of juveniles in their ranks. Juveniles are easy and cheap recruits, and make it easier for terrorist groups to attack. The main reasons why terrorists recruit juveniles are that they are cheap recruits, who also bring some tactical and strategic advantages to their operations. For example, a juvenile in the role of a suicide bomber spreads fear wider, which is the main consequence that terrorist groups intend to produce. Furthermore, there are many reasons why juveniles join terrorist groups, for example, religious motivations, economic and financial motivations, and social motivations. There are many different ways in which terrorist groups recruit and attract juveniles. Institutions that juveniles interact with, like schools, can play a significant role. A modern way of recruiting juveniles by terrorist groups is via the Internet and social networks, which is now recognised as an increasing problem. In the papers, the authors analyse reasons why terrorist groups recruit juveniles, as well as why juveniles join terrorist groups, the role that juveniles have inside the terrorist groups, and the ways they are recruited, especially via the Internet and social networks, as a modern way of recruitment.
\end{abstract}

Keywords: terrorist groups, recruitment of juveniles, juveniles' roles, social networks

\section{INTRODUCTION}

Terrorism, as a dominant security challenge worldwide in recent years, has multiple impacts on juveniles and therefore presents an increasing problem for the protection and safety of juveniles. Not only that the recruitment of juveniles by terrorist groups jeopardizes the security and safety of juveniles, but it also presents an increased threat to civilians and causes greater fear among them. So, juveniles are drown into terrorism as victims and as participants, perpetrators of terrorist acts.

Nowadays, many different reasons for recruiting juveniles by terrorist groups can be recognised, and they include both forced recruitment and joining on a voluntary basis.

\footnotetext{
* Full Professor, PhD, University of Belgrade Faculty of Security Studies,banovicb@fb.bg.ac.rs

** Teaching Assistant, Faculty of Law, University of Kragujevac, vmilekic@jura.kg.ac.rs
} 
Aetiology of these two ways of recruitment is different, but we can find the same environmental and circumstantial factors that lead to the engagement of juveniles in terrorist activities. Understanding the aetiology and phenomenology of the problem presents a useful step in the combat against terrorism.

But, the practice has shown that terrorists always find some new ways to act. Nowadays, with the global use of the Internet and social networks, it is obvious that they can be used not only for entertainment and business, but they can also be misused. Terrorists have realised the benefits of the Internet and social networks and started using them for recruitment of new members and for publishing recordings of their activities.

\section{TERRORISM}

Terrorist activities mostly have international implications, but at the beginning of the fight against terrorism, sovereign states had the dominant role. Eventually it was realised that any sovereign state by itself could not effectively fight against terrorism, but instead a comprehensive international cooperation was required. Consequently, intensive international and regional legal activity followed in order to establish a unique legal frame with the aim to fight against terrorism more effectively (Banović, 2007, p. 145.).

After many attempts to define terrorism properly, in 2000 the UN General Assembly adopted the International Convention for the Suppression of the Financing of Terrorism (UN General Assembly, 2000), which included the definition of terrorism that was later determined as a definition that encompassed the essence of terrorism. According to this Convention, terrorism includes: first, an act which constitutes an offence within the scope of and as defined in one of the treaties listed in the annex (for example, taking of hostages, terrorist bombings etc.), and second, any other act intended to cause death or a serious bodily injury to a civilian, or to any other person not taking an active part in the hostilities in a situation of armed conflict, when a purpose of such act, by its nature and context, is to intimidate a population, or to compel a Government or an international organization to do or to abstain from doing any act (article 2. (1) (a) (b)).

One of the main characteristics of terrorism is the depersonalisation of the victim, because the perpetrator of a terrorist act doesn't attack any particular victim, but he attacks the victim on a random basis. Furthermore, terrorism can manifest in many different shapes, as we could see from the definition which is not determined on the numerus clausus basis. That is why people say that terrorism has a 'chameleon nature' (Kaseze, 2005, p. 144.).

However, during all the efforts to enact and apply counter-terrorism legislation, there were only few considerations that juveniles could be some of these terrorists and that some aspects of this problem should be taken into account (Brett, 2002, p. 33.).

\section{RECRUITMENT OF JUVENILES BY TERRORIST GROUPS}

Recruitment of juvenile by terrorist groups has become a well-known practice in many countries around the world, and it is a recent phenomenon that has been developing through the last decade. The reasons why terrorist groups recruit juveniles are multiple and 
complex, also depending on the concrete situation, but the fact is that some terrorist groups, when recruiting, target particularly juveniles (UNODC, 2017, p. 10.).

There are many reasons why terrorist groups recruit juveniles and there are many researches on the aetiology of this phenomenon. We will point out to some of them. One research (UNODC, 2017, p. 10-11.) has shown that some terrorist groups, like Boko Haram and ISIL, recruit juveniles in order to boost their visibility, as means of propaganda, and to shock the public and to show the power and ruthlessness of the group. Although, there are demographic reasons, since in some countries there are more juveniles than adults, making juveniles more available for recruitment and abduction. There are also economic reasons, since juvenile recruits are usually less paid and need less food to survive. With the proliferation of small arms and light weapons, juveniles are increasingly likely to act as effectively as adults, and that is also why terrorist groups recruit them. Furthermore, juveniles' mental and physical capacities make them easier to intimidate and easier to control, and, what is particularly important they show higher degree of loyalty to authority figures. Also, recruitment of juveniles brings some tactical advantages to terrorist groups. Namely, juveniles have less understanding of the risk they are facing and they are more obedient than adults, which is why they are used as spies, porters, to carry materials and undertake suicide attacks.

According to other research, terrorist groups recruit juveniles because it is a low-cost way to build their forces, bringing tactical and strategic advantages. Additionally, there is one psychological moment: the use of suicide bombers spread fear wider than conventional terrorism, and putting juveniles in this role heightens the hysteria terrorists strive to cause (Singer, 2006, p. 118-119.).

Some terrorist groups often target orphans, the fatherless and refugees, offering them a 'the new family' and, consequently, using them for suicide bombing (Meillahn, 2008, p. 7.).

But the recruitment of juveniles by terrorist groups presents only one side of the problem, because there is much evidence around the world showing juveniles who voluntarily join terrorist groups. Aetiology of this side of the problem is also multiple and complex and presents a combination of youth's susceptibility to powerful influences and the cruel environment which shape them (Singer, 2006, pp. 119-120.). So, the first reason why juveniles join terrorist groups can be found in religious motivations. For example, in Islam there is a tendency to promote the concept of martyrdom, dying for one's faith. There are sometimes economic motivations, because juveniles from poor families and environments join terrorist groups in order to get food, clothes and shelter. Some of these groups promise to pay juvenile's family or to take care of them, if the juvenile joins the group. Schools and other institutions of importance for juveniles can also play a significant role by indoctrination, ideological education and other means of imposing attitudes and beliefs. Social environment can also influence juveniles' decisions to join, which is particularly peculiar for shame societies, where acquisition of honour and avoidance of shame present the key factor of behaviour. In some societies this can be even more pronounced, like in Sri Lanka and Pakistan, where terrorist groups give families of young suicide bombers special recognition and honours in the community. There are some personal reasons for joining terrorist groups, for example, loss of family member or close friend, other forms of 
direct suffering from violence, jailing or brutalisation from local security forces etc. (Singer, 2006, pp. 120-124.). Some of these circumstances, or their combination, can act as a push factor in relation to juvenile's decision to join terrorist groups.

Some of the other reasons or motivations that lead to their engagement within terrorist groups are: moral outrage, ideology, revenge, patriotism, financial incentives, religious incentives, prestige, as well as sense of purpose, meaning and identity. Beside these reasons, there are some particularly characteristic for female juveniles, like a response to the cultural importance placed on the male child, loss of a family member, lack of material or financial support, rape, divorce, marriage to someone the family disapproves of, rejection by society, sense of cultural humiliation etc. (Meillahn, 2008, p. 11.).

Some juveniles are born and live in an environment that is likely to make them become terrorists. For example, in Lebanon and Palestinian territories, where the cults of martyrdom exist, many juveniles, even very young children, are willing to make the ultimate sacrifice of martyrdom. Many of them have passed through the 'education' that presents psychosocial manipulation and indoctrination. Terrorists have used juveniles for different purposes, for propaganda, for fighting and even hacking off the heads of hostages (Meillahn, 2008, p. 6-7.).

According to Israeli Security Agency (sources, 2003), terrorist groups recruit children because their innocent appearance does not arouse suspicion and can easily blend in with the crowd. They are easily influenced and thus make them more convenient recruits for suicide bombing missions. Children are taken from their homes and families and schools and indoctrinated in order to carry out terrorist act, very often by convincing them that they will be granted paradise if they do so. Children are indoctrinated with extreme Islamic ideas, in schools, youth camps and via the Internet. Childhood is used in many ways by terrorists. Not only children are used to conduct terrorist activities, but also children toys are used for camouflaging their activities. Furthermore, terrorists try to camouflage their activities by acting near schools and kindergartens.

When trying to explain the aetiology and the phenomenology of the recruitment of juveniles by terrorist groups, many authors take the example of Palestinian juveniles. One of the main characteristics of the war between the Palestinians and Israelis is a large number of terrorist acts, especially suicide bombings, carried out by Palestinian juveniles. Juveniles participated in the war from its beginning, however from September 2000 the involvement of juveniles got a dark twist, because a lot of them joined different terrorist organisations and expressed a strong will to commit acts of terrorism and suicide (Rosen, 2005 , p. 92.). The Palestinians constantly attribute the terrorist acts, especially suicide bombings, to the horrific situation of the Palestinians under Israeli occupation. In that way, the responsibility for these acts is transferred to Israel. So, suicide bombers are 'double victims', first victims of Israeli occupation, and then victims of their own acts of selfannihilation in response to Israeli occupation. It is obvious that revenge is the main motive for terrorist activities (Rosen, 2005, pp. 123-124.). 


\section{THE ROLE OF THE INTERNET AND SOCIAL NETWORKS}

One of the main characteristics of the Internet and social networks is the massiveness of users. Logically, this advantage of the Internet and social networks has not been recognised only by those who use the Internet and social networks for work, fun and pleasure, but also by those who are prone to criminal activities, and among them - by terrorist groups. And this is the dark side of the fact that 'almost whole world is on the Internet'. So, the Internet by itself is not harmful, but the way it is used by some individuals or groups (Milekić, 2013, p. 177.), in this case by terrorist groups.

Cyber terrorism is a problem of the modern age. In order to find and recruit new members, terrorists use all the Internet resources and services, as well as different forums and social networks. The Internet and social networks are, as well, often used for propagation of terrorist activities and for taking responsibilities for conducted terrorist acts (Miladinović \& Petričević, 2012, p. 7.). Considering aetiological aspects, the main reasons for conducting criminal activities on the Internet and social networks are massiveness of users, informatics illiteracy, lack of awareness of security risks, difficulties in identifying criminals (in this case terrorists) etc. (Miladinović \& Petričević, 2012, pp. 2-3.). Of course, these reasons become even more pronounced in relation to juveniles. Namely, great number of users are juveniles, and juveniles are those informatics illiterates who lack awareness of security risks. The consequence is that this represents a fertile soil for terrorist groups to recruit juveniles, with little or almost no chance to be discovered and identified.

Namely, terrorist groups also use the Internet and social networks for multiple reasons. We are all familiar with videos published on the Internet with recorded activities of terrorist groups, killing or torturing someone, or with recorded messages for the international society in order to cause a fear. Terrorists have also realised that the development of many different social networks could be used as a source of new recruits, especially among juveniles who are the main users of these networks.

Some researches reveal that the use of the Internet has rapidly increased during the last decade. In 1998 there were twelve active terrorists websites, by 2003 this number increased to 2600 , and in 2009 it is estimated that there were nearly 7000 active terrorists websites (Weimann, 2009).

\section{INSIDE TERRORIST GROUPS}

Bearing in mind the nature of terrorist activities and the scope of their consequences, it is obvious that not every juvenile can conduct these activities. Also, juveniles have to pass a kind of training and preparations in order to conduct terrorist acts by themselves. Close relations inside terrorist groups increase intimacy and create the atmosphere of obedience and respect for the leader.

In accordance with the aim of a concrete terrorist act, terrorists choose juveniles very carefully. So, the selection of juveniles is the first step, and in addition to juveniles' intelligence and enthusiasm, it is very important that they can blend in with the crowd (Singer, 2006, p. 127.). After the process of selection, juveniles are subjected to training, both physical and mental. The mental training is the most important, especially when the 
juveniles' mission is to carry out a suicide attack. This training includes intense mental preparation, indoctrination, studying the texts that glorify sacrifice and ease the fear of death. Hours before the attack are spent in prayer and in recording wills and farewell messages on video or audiotapes. These videos are later used for new generations of recruits and as insurance that the bomber will carry out the attack; otherwise, he would be humiliated (Singer, 2006, pp. 127-129.).

\section{STATISTICS}

Security Council Secretary-General and Special Representative of the Secretary-General for Children and Armed Conflict submit annual reports on the issue of armed conflicts and their impact on juveniles. The impact of terrorism on juveniles around the world is analysed in some of these reports, with a special focus on different aspects of this increasing problem. As these reports are evidence-based and proved by field investigations, we consider them reliable and for that reason we will present the data contained in these reports.

According to the Annual Report of the Special Representative from 2009 (Special Representative of the Secretary-General, 2009, par. 41-43.), terrorist acts committed during conflicts in Iraq, Afghanistan and in the occupied Palestinian territory caused a lot of damage to juveniles. Terrorist attacks are directed against civil population and civil objects, and children and schools within them, constituting grave breaches of human rights in that way. But, children are also used all the time to perpetrate these attacks, because they can be more easily forces to act and they are less noticeable. Also, children are recruited and trained as suicide bombers, and used as human shields, decoys in suicide car bombings, or to transport improvised explosive devices. The other side of the problem is the impact of counter-terrorism on children. Namely, counter-terrorism measures also target juveniles, for example, through arrest and detention of juveniles because of their alleged participation in terrorist activities or associations with terrorist groups. Many of these children are detained without respect for their procedural rights according to international standards of juvenile justice.

In its Report from 2015 (Special Representative of the Secretary-General, 2015, p. 4.), in the section on emerging issues and challenges, Special Representative points to the fact that terrorist groups have benefited from advantages in technology, which have facilitated their rapid growth and led to the expansion of their territorial control, very often across national borders. The response to this development, embodied in counter-terrorism operations, has caused many children to be killed, maimed, and their homes and schools destroyed. Furthermore, terrorist groups regularly recruit juveniles from around the world using propaganda on the Internet and social media. The attention should be given to the recruitment networks of terrorist groups, with the aim of preventing them. Education of juveniles on this topic could be a very useful means of prevention.

This problem is also addressed in the next Report from 2016 (Special Representative of the Secretary-General, 2016), stating that juveniles continue to be severely affected by extremist violence and are often the direct targets of acts intended to cause maximum civilian casualties and terrorise communities. The recruitment of juveniles presents the 
prevalent concern. Social media also continues to be used for purposes of propaganda and to encourage recruitment of children.

The Final Report on Recruitment and Radicalisation of School-Aged Youth by International Terrorist Groups, prepared for the U.S. Department of Education, Office of Safe and Drug-Free Schools (Homeland Security Institute, 2009), includes the analysis of the recruitment of juveniles by the following terrorist groups: Hamas and Hizballah, A1Qaeda in the Islamic Maghreb (AQIM), Al-Qaeda and Affiliated Groups, Euskadi Ta Askatasuna (ETA) and Jemaah Islamiyah (JI).

Hamas and Hizballah strive to recruit and radicalise juveniles through active campaigns in schools, youth camps and mass media, including TV, the Internet and radio, where their activities are extreme. Juveniles are used to fill the ranks of these terrorist organisations, and carry out suicide attacks and conduct other terrorist activities. Also, they are used as human shields because these terrorist organisations know that Israeli soldiers are prohibited to shoot at children. By recruiting and radicalising juveniles as young generations, Hamas and Hizballah are establishing societal support for future operations. These terrorist groups start with recruitment at an early age, even when children are in kindergarten, and strive to gain their support and prepare recruits for future membership. They control the whole educational system, and follow their recruits all the way to college. Schools provide education that is in accordance with terrorist groups' ideologies and beliefs and also provide physical training in order to prepare juveniles for future groups' activities. Both groups sponsor summer-camps and other extra-curricular activities for juveniles. Mass media is also used for ideological purposes, where juveniles can watch cartoons and play video games that promote violence against the West. These groups have their own TV and radio stations that are used for ideological purposes and in order to recruit as more members as possible.

Jemaah Islamiyah uses Islamic schools and universities as a recruiting pool, and strives to radicalise recruited juveniles. Some of the members of this terrorist group are former students and/or instructor of these schools and universities. This terrorist group is well known for its strong familiar relations which means that juveniles often follow their relatives and join the group, and in that way the group maintains a strong and unified support in community.

Al-Qaeda and Affiliated Groups use a broad range of tactics and messages to recruit and radicalise juveniles. These groups conduct their activities all around the world, but mostly in Afghanistan, Pakistan, Iraq and the UK. Among European countries, the UK has encountered the problem of juveniles recruited by terrorist groups, because these groups methodically and intentionally target juveniles across the UK. For example, Al Qaeda recruited juveniles as young as 15 and used them for a deliberate campaign of terror in the UK, and for carrying out acts of terrorism. The reason why Al-Qaeda is looking for young recruits from Western countries is obvious - their familiarity with the language, culture and appearance. The juveniles who would not arouse any suspicion when standing beside ordinary people, are necessary for Al-Qaeda to conduct its terrorist activities against the West. The research shows that UK universities are of a particular importance, because nearly 30 terrorist groups have been identified at different campuses. In conflict zones in 
Afghanistan, Pakistan and Iraq, Al-Qaeda has cleverly used situational factors, such as personal grievances and poverty, to recruit and indoctrinate juveniles. The most used method of recruitment is by kidnapping or other means of force. Juveniles are often used to carry out suicide bombings. In these countries juveniles are seen as new generation of Mujahidins, and there is a lot of evidence showing juveniles taking part in terrorist activities.

Al-Qaeda in the Islamic Maghreb is an active terrorist organisation not only in Maghreb region, but in Europe as well. Here, schools do not play significant roles in recruitment and radicalisation of juveniles; instead, mosques and the Internet are used for these purposes.

Euskadi Ta Askatasuna has traditionally been a youth organisation and it is now recruiting even younger members. These members participate in protests, riots and street violence.

Among European countries, beside the UK, the Netherlands also has a problem with recruitment and radicalisation of juveniles. This is the case within immigrant population, with young second and third-generation of Muslims from Morocco. Radical mosques, some Islamic schools and the Internet are being used as recruiting base.

\section{CONCLUSION}

It is this characteristic of terrorism - its 'chameleon nature' - that can be correlated with the global trend of recruiting juveniles to conduct acts of terrorism. Increased international cooperation in the fight against terrorism has forced terrorists to find new ways of acting. The solution has been found in the recruitment of juveniles and their use for terrorist activities. The reason is clear and obvious - juveniles could easily blend into the crowd and they arouse less suspicion than adults. There is, however, the other side of the problem - juveniles joining terrorist groups and their engagement in terrorist activities, both on a voluntary basis.

In order to address the problem of juveniles recruited by terrorist groups and used to conduct terrorist activities, it is essential to understand aetiology and phenomenology of the problem, as well as psychophysical characteristics and maturity of juveniles. The comprehensive analysis and understanding of the phenomenon is required. This means that it should be clear why terrorists recruit juveniles, why juveniles join terrorist groups on a voluntary basis, for what purposes and tasks terrorists use juveniles, and what the role of juveniles' psychophysical characteristics and maturity is.

Research has shown that terrorists recruit juveniles for many different reasons, e.g. to boost their visibility, as means of propaganda, to shock the public, to show the power and the ruthlessness of the group, because in some countries there are more juveniles than adults, for economic reasons, since they are easier to intimidate and control due to their juvenile mental and physical capacities, because it brings some tactical advantages to terrorist groups etc.

There are also many reasons why juveniles join terrorist groups on a voluntary basis, like: religious motivations, economic motivations, because of indoctrination, ideological education and other means of imposing attitudes and beliefs, all through schools and other 
forms of formal education, social environment like violence in everyday life, personal reasons like a loss of a family member or a close friend, moral outrage, ideology, revenge, patriotism, financial incentives, religious incentives, prestige, as well as a sense of purpose, meaning and identity.

Once recruited, the juveniles receive intensive physical and mental trainings, after which they are ready to conduct a terrorist act. The researches have also shown that they are mostly used to carry out an act of suicide bombing.

One new characteristic of a terrorist method of recruitment is finding new juvenile recruits online. Earlier, terrorists used meetings and personal approaches and connections in order to find, recruit and indoctrinate juveniles, but now, with the advance and development of the Internet and social networks, they can achieve the same goals online, by acting faster, easier, from a remote distance and anonymously. Furthermore, these goals can be achieved in a wider context and with far-reaching consequences, because nowadays almost every juvenile uses the Internet or some social network. So, it can be said that the Internet and social networks make the terrorists' assignments more easily to accomplish - they can operate by sitting in the chair.

\section{REFERENCES}

Assembly, U. G. (2000). International Convention for the Suppression of the Financing the Terrorism.

Brett, R. (2002). Juvenile justice, counter-terrorism and children. Children and Security, 29-36.

Institute, H. S. (2009). Recruitment and Radicalization of School-Aged Youth by International Terrorist Groups. Arlington: Homeland Security Institute.

Kaseze, A. (2005). Međunarodno krivično pravo. Beograd: Beogradski centar za ljudska prava.

Meillahn, M. (2008). The Strategic Landscape: Avoiding Future Generations of Violent Extremists. Strategic Insight, 1-22.

Miladinović, A., \& Petričević, V. (2012). Kriminogeni aspekt društvenih mreža. Retrieved from

Academia:

http://www.academia.edu/10138697/Kriminogeni_aspekt_drustvenih_mreza

Rosen, D. (2005). Armies of the Young: Child Soldiers in War and Terrorism. New Brunswick/New Jersey/London: Rutgers University Press.

Secretary-General, S. R. (2009). Annual Report on Children and Armed Conflict. United Nations.

Secretary-General, S. R. (2015). Annual Report on Children and Armed Conflict. United Nations.

Secretary-General, S. R. (2016). Annual Report on Children and Armed Conflict. United Nations.

Singer, P. (2006). Children at War. Berkeley/Los Angeles: University of California Press. 
sources, I. s. (2003, January 14). The exploitation of children for terrorist purposes. Retrieved from Likoed Nederland: https://likud.nl/2003/01/the-exploitation-ofchildren-for-terrorist-purposes/

UNODC. (2017). Handbook of Children Recruited and Exploited by Terrorists and Violent Extremist Groups: The Role of the Justice System. Vienna: United Nations.

Weimann, G. (2009). The Internet as a Terrorist Tool to Recruit Youth. Youth Recruitment \& Radicalization Roundtable. Arlington.

Бановић, Б. (2007). Тероризам у праву Европске Уније. Правни систем Србије и стандарди ЕУ и Савета Европе, pp. 145-160.

Милекић, В. (2013). Фејсбук, приватност и криминалитет: међусобна повезаност, условљеност и друштвена реакција. Социјална мисао, 167-180. 